\title{
Seed oil and seed oil byproducts of common purslane (Portulaca oleracea L.): A new insight to plant-based sources rich in omega- 3 fatty acids
}

\author{
Spyridon A. Petropoulos ${ }^{\mathrm{a}, *}$, Ângela Fernandes ${ }^{\mathrm{b}}$, Dimitrios A. Arampatzis ${ }^{\mathrm{a}}$, \\ Nikolaos G. Tsiropoulos ${ }^{\mathrm{a}}$, Jovana Petrovićc ${ }^{\mathrm{c}}$, Marina Sokovićc ${ }^{\mathrm{c}}$, Lillian Barros ${ }^{\mathrm{b}}$, \\ Isabel C.F.R. Ferreira ${ }^{\text {b,** }}$ \\ a University of Thessaly, Department of Agriculture, Crop Production and Rural Environment, 38446, N. Ionia, Magnissia, Greece \\ ${ }^{\mathrm{b}}$ Centro de Investigação de Montanha (CIMO), Instituto Politécnico de Bragança, Campus de Santa Apolónia, 5300-253, Bragança, Portugal \\ ' University of Belgrade, Department of Plant Physiology, Institute for Biological Research "Siniša Stanković", Bulevar Despota Stefana 142, 11000, Belgrade, Serbia
}

\section{A R T I C L E I N F O}

\section{Keywords:}

$\alpha$-linolenic acid

Antimicrobial properties

Fatty acids

Linoleic acid

Omega-3 fatty acids

Portulaca oleracea

Purslane

Seed oils

\begin{abstract}
A B S T R A C T
In the present study, nutritional value, chemical composition and bioactive properties of purslane seeds, seed oils and seedcakes were examined. Data were analyzed by a one-way ANOVA, while means were compared with Tukey's HSD test. For seed oil extraction mechanical and ultrasound assisted methods were tested. Cold extraction methods (CE1 and CE2) resulted in higher oil yield (increased by $33.7 \%$ and $38.1 \%$, respectively) comparing to hot extraction (HE) method. Seeds contained the highest amount of fats and energy $(15.03 \pm 0.06 \mathrm{~g} / 100 \mathrm{~g}$ dry basis $(\mathrm{db})$ and $459 \pm 1 \mathrm{kcal} / 100 \mathrm{~g} \mathrm{db}$, respectively), while seedcakes from CE2 had the highest content in proteins and ash $(31.20 \pm 0.03$ and $4.27 \pm 0.06 \mathrm{~g} / 100 \mathrm{~g} \mathrm{db}$, respectively). Seeds and seedcakes contained a balanced content of linoleic and $\alpha$-linolenic acids (33.80-34.74\% and 32.83-34.64\%, respectively). HE and CE1 oils had slightly higher amounts of $\alpha$-linolenic $(39.67 \%$ and $39.57 \%$, respectively) than linoleic acid (35.44\% and 35.13\%, respectively), whereas CE2 oils contained twice as much linoleic as $\alpha$ linolenic acid (49.77\% and $24.18 \%$, respectively). In conclusion, the tested materials are good sources of omega6 and omega- 3 fatty acids and proteins, while extraction method affected oil yield and fatty acids composition of seed oils.
\end{abstract}

\section{Introduction}

The beneficial role of omega- 3 fatty acids to human health has increased market needs for functional foods and dietary supplements enriched with this specific type of fatty acids (Calder, 2018; Gheysen et al., 2019). The main omega-3 fatty acids associated with health beneficial properties are eicosapentaenoic acid (EPA) and docosahexaenoic acid (DHA) which are commonly found in seafood and microalgae, and $\alpha$-linolenic acid (ALA), which is most commonly found in plants (Perona, Garcia-Rodrigue, \& Castellano, 2018). Nowadays, the recommended daily dose for omega- 3 fatty acids (250-500 mg/day) is met through seafood consumption or dietary supplements containing fish oils, which are rich in EPA and DHA, whereas a very small proportion of daily intake is attributed to plant-based dietary sources (Andre et al., 2019; Tocher, 2015). Despite the well-known beneficial effect of long and very long fatty acids (LCFA and VLCFA, respectively), consumption in many countries does not meet daily requirements due to particularities of specific consumer groups which are reluctant to consumption of fish products (e.g. tuna, mackerel, salmon, herring and sardines) or due to inability of world fish production to meet global population needs in LCFA and VLCFA (Salem \& Eggersdorfer, 2015; Tocher, Betancor, Sprague, Olsen, \& Napier, 2019). Therefore, there is an urgent need to find alternative sources of such fatty acids taking into special consideration that terrestrial plants are sources of ALA which is also associated with beneficial effects and can be metabolized in human body to EPA and DHA (Dubois, Breton, Linder, Fanni, \& Parmentier, 2007; Perona et al., 2018).

Various plants have been indicated as rich sources of omega- 3 fatty acids, some of which are currently being used in the food and pharmaceutical industry (Dubois et al., 2007). Vegetable oils from species such as sacha inchi (Plukenetia volubilis), linseed (Linum usitatissimum) and perilla (Perilla frutescens) are rich in ALA (45-50\%, 52-55\%, and 47-64\% for sacha ichi, linseed and perilla respectively; Kim et al., 2019; Tavarini et al., 2019; Wang, Zhu, \& Kakuda, 2018) and

\footnotetext{
${ }^{*}$ Corresponding author. University of Thessaly, School of Agricultural Sciences, Fytokou Street, 38446, N. Ionia, Magnissia, Greece.

** Corresponding author.

E-mail addresses: spetropoulos@uth.gr (S.A. Petropoulos), iferreira@ipb.pt (I.C.F.R. Ferreira).
} 
monounsaturated fatty acids (MUFA), whereas chia (Salvia hispanica) and purslane (Portulaca oleracea) contain ALA (61.3\% and $32.4 \%$ for chia and purslane, respectively) and linoleic acid (LA) in amounts that account to omega-6/omega-3 ratios with values lower than 4 , indicating high nutritional value (Dubois et al., 2007; Guil-Guerrero \& Rodríguez-García, 1999). Genetically modified and transgenic plants have been also suggested as potential sources of EPA and DHA in aquaculture to replace direct use of fish oils for fish feeding (Tocher, 2015; Tocher et al., 2019). However, climate change and competition of weeds with conventional crops under unfavorable conditions should be also considered and alternative crops resilient to environmental constraints could be an option for plant sources rich in omega-3 fatty acids (Karkanis, Ntatsi, Alemardan, Petropoulos, \& Bilalis, 2019).

Purslane is a wild edible species with wide distribution throughout the world, which is traditionally consumed raw as salad or cooked in many dishes of the broader Mediterranean region (Gonnella et al., 2010; Petropoulos, Karkanis, Martins, \& Ferreira, 2016). Its medicinal and therapeutic properties are well known since centuries ago and several scripts describe its cultivation for medicinal purposes (Gonnella et al., 2010). The main edible parts are the aerial parts of the plant (leaves and stems), which have been characterized in terms of chemical composition and nutritional value in numerous reports (Oliveira et al., 2009; Palaniswamy, McAvoy, \& Bible, 2004; Petropoulos et al., 2015). Aerial plant parts have a high nutritional value due to the presence of high amounts of ALA, however the high oxalic acid and nitrates content hampers the wide acceptance of the species in human diet (Gonnella et al., 2010). According to ethnobotanical studies, seeds can also be consumed by humans and animals, while they also possess medicinal properties similar to aerial parts (Bosi, Guarrera, Rinaldi, \& Mazzanti, 2009). Seed extracts have been associated with antibacterial activities against Staphylococcus aureus (Tayel et al., 2018), while Nazeam, ElHefnawy, Omran, and Singab (2018) and Jalali Mousavi, Niazmand, and Shahidi Noghabi (2015) have highlighted the antihyperlipidemic and antioxidant properties of purslane seeds. Seed oils are very nutritious since they are rich in PUFA consisting mainly of LA, ALA and oleic acid (OA), while they also contain phenolic compounds (protocatechuic and $p$-hydroxybenzoic acids) and phenolic lipids (alkylresorcinols) (Gunenc, Rowland, Xu, Marangoni, \& Hosseinian, 2019; Kavosi, Mohammadi, Shojaee-Aliabadi, Khaksar, \& Hosseini, 2018). However, considering.

Market needs for alternative sources of omega- 3 fatty acids and the limited world production of fish oils justify the use of terrestrial sources of PUFA. Purslane could be a potential candidate species for this purpose which is already consumed for its edible leaves and stems, whereas no common use of seeds and seed oils is registered. The high content of purslane aerial parts in antinutritional factors (oxalic acid and nitrates) has hampered so far the commercial exploitation of the species as an alternative vegetable crop. Therefore, the aim of the present study was to evaluate chemical composition and any cytotoxic effects of other plant parts and by-products such as raw seeds, seed oils and seedcakes in order to suggest them as potential alternative/complementary matrices for the pharmaceuticals and cosmetics industry, as well as for the food industry. Moreover, the effect of extraction methods on seed oil yield and oil chemical composition was also tested.

\section{Materials and methods}

\subsection{Standards and reagents}

Acetonitrile $99.9 \%, n$-hexane $95 \%$ and ethyl acetate $99.8 \%$ were of high-performance liquid chromatography (HPLC) grade from Lab-Scan (Lisbon, Portugal). The fatty acids methyl ester (FAME) reference standard mixture 37 (standard 47885-U) was purchased from SigmaAldrich (St. Louis, MO, USA), as also other individual fatty acid isomers, tocoferols standards ( $\alpha-, \beta-, \delta$-, and $\lambda$-isoforms, $>98 \%$ HPLC purity), sugars standards $(\mathrm{D}(-)$-fructose, $\mathrm{D}(+)$-glucose, $\mathrm{D}(+)$-melezitose, $\mathrm{D}$ $(+)$-sucrose and $\mathrm{D}(+)$-trehalose; $>98 \%$ HPLC purity), gallic acid ( $\geq 99 \%$ HPLC purity), and organic acids standards (oxalic and macic acids; $\geq 99 \%$ HPLC purity). Racemic tocol (98\% HPLC purity), $50 \mathrm{mg}$ / $\mathrm{mL}$, was purchased from Matreya (PA, USA). Mueller-Hinton agar (MH) and malt agar (MA) were obtained from the Institute of Immunology and Virology, Torlak (Belgrade, Serbia). Dimethylsulfoxide (DMSO) was perched by Merck KGaA, Germany. Fetal bovine serum (FBS), Hank's balanced salt solution, non-essential amino acid solution ( $2 \mathrm{mmol} / \mathrm{L})$, penicillin/streptomycin solution $(100 \mathrm{U} / \mathrm{mL}$ and $100 \mu \mathrm{g} /$ $\mathrm{mL}$, respectively) and Dulbecco's Modified Eagle's Medium (DMEM) were from Hyclone (Logan, UT, USA). Acetic acid, ellipticine and sulforhodamine B (SRB) were from Sigma-Aldrich (St Louis, MO, USA). All other chemicals were of analytical grade and were obtained from common sources. Water was treated in a Mili-Q water purification system (TGI Pure Water Systems, USA).

\subsection{Plant material and growing conditions}

The experiment was carried out at the experimental field of the University of Thessaly, in Velestino (Greece) during the summer growing period of 2017. Purslane seeds were purchased from Hortus Sementi Srl. (Budrio, Italy) and sown directly in soil (May 10, 2017) with a distance of $30 \mathrm{~cm}$ and $5 \mathrm{~cm}$ between rows and within rows, respectively. The experimental included three plots of $5 \times 5 \mathrm{~m}$ (25 $\times 3=75 \mathrm{~m}^{2}$ in total). Before sowing, base dressing was applied at a rate of $100 \mathrm{~kg} / \mathrm{ha}$ (10-10-10; N-P-K). A sprinkler irrigation was implemented for irrigation at regular intervals (once every week and after sowing and until 10 days before harvesting). Soil was sandy clay loam ( $38 \%$ sand, $36 \%$ silt, and $26 \%$ clay), with $\mathrm{pH}=7.4\left(1: 1\right.$ soil $\left./ \mathrm{H}_{2} 0\right)$ and organic matter content $=1.3 \%$, while no pesticides or other agrochemicals were used. Harvest of seeds took place on July 11, 2017 by cutting plants with a harvesting knife, while for seed yield assessment samples from 3 random squares of $1 \mathrm{~m}^{2}$ in each plot were considered. A second harvest was applied at the last fortnight of August 2017 from resprouting plants and seed yield was estimated as mentioned before.

After each harvest, batch samples of seeds were used for oil extraction, while seeds and the obtained seed-cakes from each extraction method (see section 2.3) were ground with an electric ball mill (PXMFC $90 \mathrm{D}$, Kinematica AG, Switzerland), stored at $-20{ }^{\circ} \mathrm{C}$, and then were lyophilized. The lyophilized samples were put in plastic air-sealed bags and stored at $-80{ }^{\circ} \mathrm{C}$ until further analysis.

\subsection{Seed oil extraction methods}

For seed oil extraction, seeds from both harvests were used according to the method previously described by the authors (Petropoulos et al., 2018). Briefly, two mechanical methods were implemented (hot and cold extraction). Oil extraction with mechanical pressing is widely used in vegetable oil industry and implements screw presses that force oil out of plant material. The main difference between hot and cold extraction methods is the use of a cooling module in the latter that allows oil extraction without increasing its temperature due to pressing forces. Hot extraction (HE) was performed with the small type screw oil press TäbyPressen Type 40 (Skeppsta Maskin AB, Örebro, Sweden), where oil temperature during the extraction ranged between 53 and $55{ }^{\circ} \mathrm{C}$. The details of oil extraction procedure have been previously described by Petropoulos et al. (2018) (nozzle diameter: $6 \mathrm{~mm}$; seed feeding: $5 \mathrm{~kg} / \mathrm{h}$; rotational speed: $78 \mathrm{rpm}$ ). Cold extraction was carried out with CE1 and CE2 methods. The CE1 method was carried out by Amygdalea S.A. (Volos, Greece) with the use of a Komet DD 85G twin screw vegetable oil expeller equipped with a jacketed cooling system (IBG Monforts Oekotec GmbH \& Co.KG; Mönchengladbach, Germany) and according to the conditions previously described by Petropoulos et al. (2018) (nozzle diameter: $4 \mathrm{~mm}$; seed feeding rate: $20 \mathrm{~kg} / \mathrm{h}$; rotational speed: $65 \mathrm{rpm}$ ). The CE2 method was performed by Giachanas Cold Pressed Seed Oils S.A. (Evros, Greece) with the use of a Henan 
6 YL-160 screw oil press (Henan VIC Machinery Co. Ltd; Henan, China). Oil temperatures during cold extraction 2 (CE2) were retained between 22 and $24{ }^{\circ} \mathrm{C}$ with the use of a jacketed cooling system, while seedcake dimensions were between 0.8 and $1.5 \mathrm{~mm}$ (this expeller is not provided with a nozzle for seedcake output), and seed feeding rate and rotational speed were adjusted at $33 \mathrm{~kg} / \mathrm{h}$ and $130 \mathrm{rpm}$, respectively. All extraction methods were carried out in triplicate. Before analyses, oils from all methods were subjected to centrifugation twice $(3500 \times g$ for $10 \mathrm{~min}$ ) and supernatants were put in dark vials for storage (room temperature and dark conditions) until analysis.

Extraction yield (\%) of each method was calculated as the amount of oil ( $\mathrm{g}$ ) per total amount of seeds ( $\mathrm{g}$ of dry basis (db)). Moreover, Soxhlet and ultrasonic assisted extractions were used to estimate the total amount of oil contained in ground seeds and seeds cakes and further to evaluate the oil recovery (\%) for each of the tested mechanical methods (Arampatzis, Karkanis, \& Tsiropoulos, 2019). In particular, ground raw seeds and seedcake samples (5.0 g) were extracted with $200 \mathrm{~mL}$ of hexane by refluxing in a Soxhlet apparatus, for 4-8 h ( $\sim 32$ cycles, using a Soxhlet extractor with the capacity of $250 \mathrm{~mL}$ ) to assess oil recovery. The ultrasonic-assisted extraction of oil from seeds and seedcakes was carried out at room temperature by putting $1 \mathrm{~g}$ of powdered samples in $30 \mathrm{~mL}$ of hexane and then applying direct sonication $\left(35 \mathrm{kHz}\right.$ probe, $285 \mathrm{~W}$, and $29^{\circ} \mathrm{C}$ ) for $30 \mathrm{~min}$ (Elma TRANSSONIC T 460/H, Auckland, New Zealand) (Saleh et al., 2015). In both methods (ultrasonic-assisted and Soxhlet), the solvent was removed under reduced pressure for $1 \mathrm{~h}$ at $40{ }^{\circ} \mathrm{C}$ (rotary evaporator Büchi R-210, Flawil, Switzerland), in order to estimate the oil content. The dried extracts were reconstituted in $25 \mathrm{~mL}$ methanol and stored until the analysis for fatty acids composition.

\subsection{Chemical analyses}

\subsubsection{Nutritional value}

The proximate composition (moisture, proteins, fat and ash) were analytically determined in lyophilized purslane samples (Zirbus $\mathrm{GmbH}$ Sublimator $4 \times 5 \times 6$ freeze dryer) following the Official Methods of Analysis (AOAC, 2016) while total carbohydrates were calculated by difference. The lyophilization procedure was applied as follows: a) cooling of the product to a final temperature of $-55^{\circ} \mathrm{C}$ at atmospheric pressure (1000 mbar) for $4 \mathrm{~h}, \mathrm{~b}$ ) heating to a shelf temperature of $0{ }^{\circ} \mathrm{C}$ under a vacuum of $0.15 \mathrm{mbar}$ for $18 \mathrm{~h}, \mathrm{c}$ ) heating to a shelf temperature of $25{ }^{\circ} \mathrm{C}$ under a vacuum of 0.15 mbar for $24 \mathrm{~h}$. The crude protein content of the samples was determined following the macro-Kjeldahl method $(N \times 6.25)$, the total fat using a Soxhlet apparatus with petroleum ether as the extraction solvent, and the ash content by sample incineration at $550 \pm 15{ }^{\circ} \mathrm{C}$. Total carbohydrates were calculated by its difference, using the following equation: Total carbohydrates $(\mathrm{g} /$ $100 \mathrm{~g} \mathrm{db})=100-(\mathrm{g}$ fat $+\mathrm{g}$ protein $+\mathrm{g}$ ash $)$ (FAO, 1998a). Total energy was calculated according to the following equation: Energy $(\mathrm{kcal} / 100 \mathrm{~g} \mathrm{db})=4 \times(\mathrm{g}$ of proteins $+\mathrm{g}$ of carbohydrates $)+9 \times(\mathrm{g}$ of fat) or $\mathrm{kJ} / 100 \mathrm{~g} \mathrm{db}=17 \times$ ( $\mathrm{g}$ of proteins $+\mathrm{g}$ of carbohydrates $)+37 \times(\mathrm{g}$ of fat $)(\mathrm{FAO}, 1998 \mathrm{~b})$.

\subsubsection{Tocopherols}

Tocopherols were determined in lyophilized purslane samples following a procedure previously described by Dias et al. (2013) and analyzed by high-performance liquid chromatography (HPLC) (Knauer, Smartline system 1000, Berlin, Germany) coupled to a fluorescence detector (FP-2020; Jasco, Easton, MD, USA). The fluorescence detector was programmed for excitation at $290 \mathrm{~nm}$ and emission at $330 \mathrm{~nm}$. The compounds were identified by chromatographic comparisons with authentic standards and tocol was used as the internal standard (IS). Quantification was based on calibration curves obtained from commercial standards of each compound using the internal standard (IS) methodology. The results were expressed in mg per $100 \mathrm{~g}$ of dry basis (db).

\subsubsection{Free sugars}

The composition of the free sugars was determined according to a methodology previously described by Barros et al. (2013b). HPLC mentioned above coupled to a refractive index detector (Knauer Smartline 2300) was the chosen methodology, the data were analyzed using Clarity 2.4 Software (DataApex, Prague, Czech Republic). Identification was carried out by comparing authentic standard retention times, while quantification (DataApex, Podohradska, Czech Republic) was achieved using the IS method (melezitose as IS), by applying calibration curves constructed from authentic standards. Free sugars were further expressed in $\mathrm{g} / 100 \mathrm{~g} \mathrm{db}$.

\subsubsection{Organic acids}

Samples $(\sim 1.5 \mathrm{~g})$ were extracted by stirring with $25 \mathrm{~mL}$ of metaphosphoric acid $\left(25^{\circ} \mathrm{C}\right.$ at $150 \mathrm{rpm}$ ) for $45 \mathrm{~min}$ and subsequently filtered through Whatman no. 4 paper. After, the samples were filtered through $0.2 \mu \mathrm{m}$ nylon filters and the analysis was performed using a Shimadzu 20A series UFLC (Shimadzu Corporation, Kyoto, Japan) coupled to photodiode array detector (PDA) (Barros, Pereira, \& Ferreira, 2013). Separation was achieved on a SphereClone (Phenomenex, Torrance, CA, USA) reverse phase $\mathrm{C} 18$ column $(5 \mu \mathrm{m}, 250 \mathrm{~mm} \times 4.6 \mathrm{~mm}$ i.d. internal diameter.) thermostatted at $35^{\circ} \mathrm{C}$. Detection was carried out in a PDA using $215 \mathrm{~nm}$ as preferred wavelengths. For the quantitative analysis, calibration curves with known concentrations of commercial standards were constructed, and the organic acids present in the samples were determined by peak area comparison at $215 \mathrm{~nm}$. The results were expressed in $\mathrm{g} / 100 \mathrm{~g} \mathrm{db}$.

\subsubsection{Fatty acids}

Fatty acid content was determined after trans-esterification of the lipid fraction obtained through Soxhlet extraction as previously described by Obodai et al. (2017). Briefly, fatty acids were methylated with $5 \mathrm{~mL}$ of methanol:sulphuric acid:toluene 2:1:1 (v:v:v), during at least $12 \mathrm{~h}$ in a bath at $50{ }^{\circ} \mathrm{C}$ and $160 \mathrm{rpm}$; then $3 \mathrm{~mL}$ of deionized water were added, to obtain phase separation; the FAME were recovered with $3 \mathrm{~mL}$ of diethyl ether by shaking in vortex, and the upper phase was passed through a micro-column of sodium sulphate anhydrous, in order to eliminate the water; the sample was recovered in a vial with Teflon, and before injection the sample was filtered with $0.2 \mu \mathrm{m}$ nylon filter from Merck Millipore (Oeiras, Portugal). The analysis was carried out using a DANI model GC 1000 instrument equipped with a split/splitless injector set at $250{ }^{\circ} \mathrm{C}$ with a split ratio of $1: 50$, a flame ionization detector (FID) (GC-FID; DANI1000, Contone, Switzerland) set at $260{ }^{\circ} \mathrm{C}$ and a Zebron-Kame column $(30 \mathrm{~m} \times 0.25 \mathrm{~mm}$ ID $\times 0.20 \mu \mathrm{m} d$, Phenomenex, Lisbon, Portugal). The following oven temperature program was used: initial temperature of $100{ }^{\circ} \mathrm{C}$, held for $2 \mathrm{~min}$, then a $10{ }^{\circ} \mathrm{C} / \mathrm{min}$ ramp to $140{ }^{\circ} \mathrm{C}, 3{ }^{\circ} \mathrm{C} / \mathrm{min}$ ramp to $190{ }^{\circ} \mathrm{C}, 30^{\circ} \mathrm{C} / \mathrm{min}$ ramp to $260{ }^{\circ} \mathrm{C}$ and held for $2 \mathrm{~min}$. Hydrogen was used as the carrier gas with a flow-rate of $1.1 \mathrm{~mL} / \mathrm{min}$, measured at $100{ }^{\circ} \mathrm{C}$. Fatty acid identification and quantification was performed by comparing the relative retention times of FAME peaks from samples with those of standards (reference standard mixture 47,885-U, Sigma, St. Louis, MO, USA). The results were recorded and processed using the Software Clarity DataApex 4.0 Software (Prague, Czech Republic) and expressed in relative percentage of each fatty acid.

\subsection{Bioactive properties}

\subsubsection{Extraction methodology}

A hydroethanolic extract was obtained by stirring the raw material $(1 \mathrm{~g})$ in an aqueous ethanolic solution $(80 \%$ ethanol, $v / v ; 30 \mathrm{~mL})$ at room temperature $\left(25^{\circ} \mathrm{C}\right.$ ) for $60 \mathrm{~min}$. After filtration (Whatman no. 4), the extraction procedure was repeated once. Then, the solvent was recovered in order to obtain a dry extract: first, evaporation at $40{ }^{\circ} \mathrm{C}$ and reduced pressure (rotary evaporator Büchi R-210, Flawil, Switzerland), and then freeze-drying (FreeZone 4.5, Labconco, Kansas 
City, MO, USA).

\subsubsection{Total phenolic compounds (TPC)}

The total phenolic compounds were determined in the extracts (seeds and seedcakes) and in the oils, by applying the Folin-Ciocalteu methodology with some modification performed by the authors (Sarmento, Barros, Fernandes, Carvalho, \& Ferreira, 2015). The absorbance was measured at $765 \mathrm{~nm}$ (AnalytikJena 200 spectrophotometer, Jena, Germany) and gallic acid was used as a reference compound to obtain the calibration curve $(0.05-0.8 \mathrm{mM} ; Y=1.7967 X+0.0274$; $\left.R^{2}=0.9997\right)$. The results were expressed as $\mathrm{mg}$ of gallic acid equivalents (GAE) per gram of extract or mg GAE per $g$ of oil.

\subsubsection{Antimicrobial assays}

To determine the antimicrobial activity, a panel of Gram-positive bacteria [Bacillus cereus (ATCC 11632), Mariniluteicoccus flavus (ATCC 10240), Bacillus cereus (food isolate) and Listeria monocytogenes (NCTC 7973)], Gram-negative bacteria [Escherichia coli (food isolate)] and fungi [Aspergillus fumigatus (ATCC 9197), Aspergillus niger (ATCC 6275), Aspergillus versicolor (ATCC 11730), Penicillium funiculosum (ATCC 36839) and Trichoderma viride (IAM 5061)] were used. The antimicrobial assay was carried out by the microdilution methodology as previously described by Petropoulos et al. (2019). The concentrations that completely inhibited bacterial growth (minimum inhibitory concentration: MICs) were determined by a colorimetric microbial viability assay, and MBC and MFC (minimum bactericidal concentration and minimum fungicidal concentration, respectively) were also calculated. Streptomycin, ampicillin, ketoconazole and bifonazole (Sigma-Aldrich, St. Louis, MO, USA) were used as positive controls and 5\% dimethyl sulfoxide (DMSO) was used as a negative control.

\subsubsection{Hepatotoxic activity}

Hepatotoxic activity was evaluated following the methodology previously described by the authors (Abreu et al., 2011), using a primary cell culture (PLP2) prepared from a porcine liver. The results were measured through the Sulforhodamine B method and results were expressed as $\mathrm{GI}_{50}$ values (concentration that inhibits $50 \%$ of cell growth). Ellipticine was used as positive control.

\subsection{Statistical analysis}

For each experimental plot, three samples of seeds were collected for seed yield evaluation ( $\mathrm{n}=3$ ), while for chemical composition analyses and oil extraction methods three batch samples from the all collected seeds were also used $(n=3)$. For statistical analysis of chemical composition and bioactivity assays, three batch samples were analyzed for each extraction method, while all the performed assays were carried out in triplicate. Statistical analysis was performed with Statgraphics 5.1.plus (Statpoint Technologies, Inc., VA, USA). Since the outcome variables displayed normal distributions, data were evaluated by one-way ANOVA, while the means of values were compared with Tukey's HSD test. All significance level was set at less than 0.05 .

\section{Results and discussion}

The results regarding nutritional value and the content of sugars, tocopherols and organic acids are presented in Table 1. Seeds and seedcakes obtained from CE2 method contained the highest moisture content, while seeds had also the highest fat content and energy. Similar results have been reported by Vioque, Pastor, and Vioque (1994) who studied seed oils from several wild species and obtained yields within the same range of our study (18.2\%). Seedcakes obtained from hot extraction (HE) had the highest fat content, which also indicates the lower oil extraction yield of hot extraction method comparing to cold extraction methods $(45.7 \%, 61.1 \%$ and $63.1 \%$ for HE, cold extraction 1 (CE1) and cold extraction 2 (CE2) methods, respectively) since more oil remained in seedcakes after the extraction procedure (Fig. 1a). Protein and ash contents were the highest for seedcakes obtained from CE2 method, whereas CE1 had the highest carbohydrates content. Extraction method has a significant effect $(p \leq 0.05)$ on seed oil extraction yield from oleaginous plants and all the processing steps have to be optimized depending on seed characteristics in order to achieve the highest extraction efficiency. According to Ionescu et al. (2014), mechanical extraction or pressing methods for oil extraction are commonly used in oil the production industry as the most cost effective methods; however, several parameters have to be considered for higher oil extraction efficiency, including screw or rotational speed, restriction size or nozzle diameter, seed morphology (size, shape), seed moisture content, temperature and pressure applied during the pressing process. The differences in pressing parameters between the methods tested in our study could explain the observed differences in oil extraction yield and consequently in the fat and protein content of the obtained seedcakes. Therefore, customized screw presses with specifications optimized for very small seeds such as purslane seed should be considered to increase the efficiency of oil extraction (Ionescu et al., 2015).

Sucrose was the only detected sugar and the highest content was detected in seeds, followed by seedcakes from CE2, CE1 and HE methods (Table 1). To the best of our knowledge, this is the first report for free sugars composition in purslane seeds and seedcakes. However, sucrose has been reported as the main detected soluble sugar in cardoon and rapeseed seeds (Hill, Morley-Smith, \& Rawsthorne, 2003; Petropoulos et al., 2019), since hexose sugars content decreases and sucrose content increases during seed development to provide the adequate energy for the developing embryo through the inversion of sucrose to glucose and fructose (Hill et al., 2003). Regarding the tocopherols content, only two vitamin $\mathrm{E}$ isomers were detected in the tested samples, namely $\alpha$ - and $\gamma$-tocopherol, with the latter being the most abundant, especially in seeds where the highest content was observed (Table 1). Similar results have been reported for okra seeds where $\alpha$ - and $\gamma$-tocopherol were also the only vitamin E isomers detected (Petropoulos et al., 2017), whereas to the best of our knowledge no previous studies for tocopherol content in purslane seeds and seedcakes have been reported. Oxalic acid was the only organic acid detected in seeds and seedcakes obtained from different extraction methods, while traces of malic acid were also recorded (Table 1). The highest content of oxalic acid was observed in seedcakes obtained from CE1, followed by seedcakes from HE, whereas seedcakes from CE2 and seeds contained low amounts of oxalic acid and total organic acids content. To the best of our knowledge, this is the first report for organic acid composition in purslane seeds and seedcakes.

Seed yield was $1100 \mathrm{~kg} /$ ha for the 1 st harvest and $125.3 \mathrm{~kg} / \mathrm{ha}$ for the 2 nd harvest, resulting in a total of $1225.3 \mathrm{~kg} / \mathrm{ha}$ (data not shown). A previous study by Ghamari, Shafagh Kolvanagh, Sabaghpour, and Dabbagh Mohammadi Nassab (2016) reported significantly lower seed yield of purslane comparing to our study (355.3-605.1 kg/ha), which could be attributed partly to lower plant densities and/or differences in the genotypes tested (wild ecotypes comparing to improved cultivars). Oil seed content in the 2nd harvest was considerably low $(17.6 \%$ and $10.6 \%$ in the 1 st and 2nd harvest, respectively) suggesting that extending the growing period by performing a 2nd harvest would not result in a significant increase of total oil yield per hectare. However, taking into account the short growing period from sowing to seed harvesting (60-75 days after sowing) it worth's investigating the application of two consecutive growing seasons, especially in warmer regions where high temperatures early in the spring allow for early sowing providing the adequate time for one more late sowing.

Fatty acids composition of the studied seeds, seed oils and seedcakes is presented in Table 2. In all the tested materials, the main detected fatty acids were two PUFA, namely linoleic and $\alpha$-linolenic acids, followed by palmitic, oleic and stearic acids although significant $(p \leq 0.05)$ differences in fatty acids were observed. In particular, seed oils obtained with CE2 contained the highest amounts of linoleic acid 
Table 1

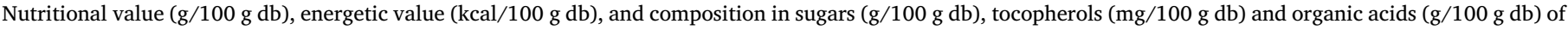
the studied purslane seeds and seedcakes (mean $\pm \mathrm{SD}$ ).

\begin{tabular}{|c|c|c|c|c|}
\hline & Seeds & Seedcake $(\mathrm{HE})^{\mathrm{a}}$ & Seedcake (CE1) & Seedcake (CE2) \\
\hline Energy (kj/100 g db) & $1920 \pm 4 a$ & $1779 \pm 6 b$ & $1734 \pm 2 c$ & $1718 \pm 1 d$ \\
\hline Energy (kcal/100 g db) & $459 \pm 1 \mathrm{a}$ & $425.1 \pm 0.1 b$ & $414.5 \pm 0.5 c$ & $410.6 \pm 0.2 \mathrm{~d}$ \\
\hline Moisture content $(\%, w b)$ & $9.65 \pm 0.03 a$ & $6.58 \pm 0.03 c$ & $8.22 \pm 0.11 b$ & $9.56 \pm 0.04 \mathrm{a}$ \\
\hline Fat $(g / 100 \mathrm{~g} \mathrm{db})$ & $15.03 \pm 0.06 a$ & $8.16 \pm 0.06 b$ & $5.85 \pm 0.09 c$ & $5.55 \pm 0.01 \mathrm{~d}$ \\
\hline Proteins $(\mathrm{g} / 100 \mathrm{~g} \mathrm{db})$ & $27.58 \pm 0.01 \mathrm{~d}$ & $30.8 \pm 0.3 c$ & $31.0 \pm 0.2 b$ & $31.20 \pm 0.03 \mathrm{a}$ \\
\hline Ash $(g / 100 \mathrm{~g} \mathrm{db})$ & $4.0 \pm 0.1 b$ & $3.92 \pm 0.05 c$ & $3.68 \pm 0.05 d$ & $4.27 \pm 0.06 \mathrm{a}$ \\
\hline Carbohydrates (g/100 g db) & $53.43 \pm 0.04 \mathrm{~d}$ & $57.2 \pm 0.3 c$ & $59.4 \pm 0.1 \mathrm{a}$ & $58.98 \pm 0.01 b$ \\
\hline Energy (kcal/100 g db) & $459 \pm 1 \mathrm{a}$ & $425.1 \pm 0.1 b$ & $414.5 \pm 0.5 c$ & $410.6 \pm 0.2 \mathrm{~d}$ \\
\hline Sucrose $(\mathrm{g} / 100 \mathrm{~g} \mathrm{db})$ & $6.48 \pm 0.06 a$ & $3.85 \pm 0.01 \mathrm{~d}$ & $4.0 \pm 0.1 \mathrm{c}$ & $6.36 \pm 0.02 b$ \\
\hline Total Sugars $(\mathrm{g} / 100 \mathrm{~g} \mathrm{db})$ & $6.48 \pm 0.06 \mathrm{a}$ & $3.85 \pm 0.01 d$ & $4.0 \pm 0.1 c$ & $6.36 \pm 0.02 b$ \\
\hline$\alpha$-Tocopherol (mg/100 g db) & $0.016 \pm 0.001 b$ & $0.026 \pm 0.002 \mathrm{a}$ & $0.012 \pm 0.001 \mathrm{c}$ & $0.011 \pm 0.002 c$ \\
\hline$\gamma$-Tocopherol $(\mathrm{mg} / 100 \mathrm{~g} \mathrm{db})$ & $3.7 \pm 0.2 \mathrm{a}$ & $2.78 \pm 0.05 b$ & $1.96 \pm 0.02 c$ & $1.99 \pm 0.09 c$ \\
\hline Total Tocopherols (mg/100 g db) & $3.7 \pm 0.2 \mathrm{a}$ & $2.81 \pm 0.05 b$ & $1.97 \pm 0.01 \mathrm{~d}$ & $2.00 \pm 0.08 c$ \\
\hline Oxalic acid (g/100 g db) & $0.520 \pm 0.005 d$ & $0.740 \pm 0.006 \mathrm{~b}$ & $0.760 \pm 0.001 \mathrm{a}$ & $0.530 \pm 0.001 c$ \\
\hline Malic acid $(\mathrm{g} / 100 \mathrm{~g} \mathrm{db})$ & $\operatorname{tr}$ & $\operatorname{tr}$ & $\operatorname{tr}$ & $\operatorname{tr}$ \\
\hline Total organic acids $(\mathrm{g} / 100 \mathrm{~g} \mathrm{db})$ & $0.520 \pm 0.005 \mathrm{~d}$ & $0.740 \pm 0.006 \mathrm{~b}$ & $0.760 \pm 0.001 \mathrm{a}$ & $0.530 \pm 0.001 c$ \\
\hline
\end{tabular}

Different Latin letters in the same row refer to significant differences between seedcakes and seeds according to Tukey's HSD test ( $p \leq 0.05$ ).

${ }^{\text {a }}$ HE: Hot extraction; CE1: Cold extraction 1; CE2: Cold extraction 2; tr: traces; db: dry basis; wb: wet basis.

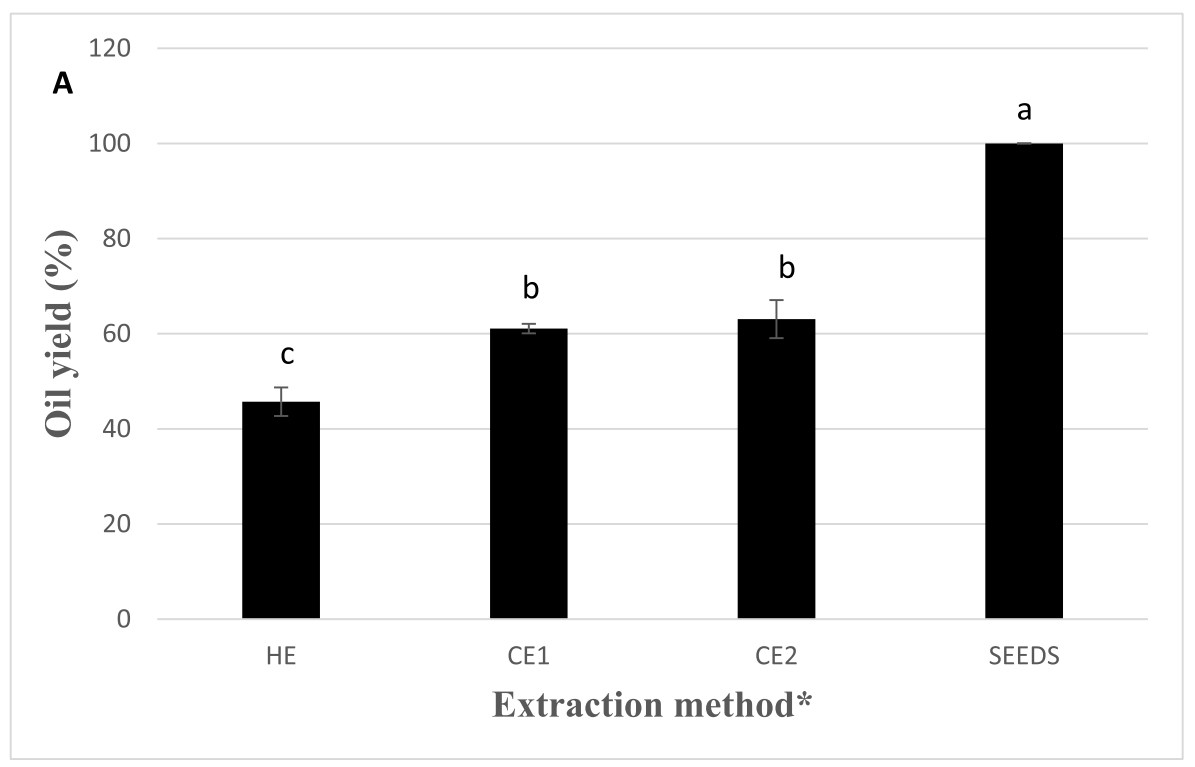

Fig. 1A. Oil yield (\%) in relation to extraction method. Each extraction methods is compared with raw seeds which is considered to contain $100 \%$ of oil. Different Latin letters indicate differences between the tested extraction methods according to Tukey's HSD test $(p \leq 0.05)$.

*HE: Hot extraction; CE1: Cold extraction 1; CE2: Cold extraction 2.

(49.77\%), whereas seed oils obtained with HE were the most abundant in $\alpha$-linolenic acid. On the other hand seedcakes obtained with HE, CE1 and CE2 were the most abundant in palmitic, oleic and stearic acids, respectively. Similar results have been reported by Stroescu, StoicaGuzun, Ghergu, Chira, and Jipa (2013), Mousavi and Niazmand (2017), and Kavosi et al. (2018) who also detected higher amounts of linoleic than $\alpha$-linolenic acid in oils obtained with solvent extraction regardless of the solvent used. Moreover, Delfan-Hosseini, Nayebzadeh, Mirmoghtadaie, Kavosi, and Hosseini (2017) evaluated three procedures for purslane seed oil extraction, namely solvent, cold press and microwave assisted cold press extraction and also observed a higher amount of linolenic acid than $\alpha$-linolenic acid. In contrast, Vioque et al. (1994) reported a different fatty acids profile in seed oils with palmitic and stearic acid being the most abundant fatty acids, while Sodeifian, Ardestani, Sajadian, and Moghadamian (2018) detected higher amounts of $\alpha$-linolenic than linoleic acid in oils obtained with supercritical fluid extraction. These differences in the literature reports indicate that extraction method has a significant effect on fatty acids profile and optimization of extraction protocols is needed to obtain oils of the desired quality (Stroescu et al., 2013). PUFA were the most abundant class of fatty acids in all the tested materials, mainly due to the high content of linoleic and $\alpha$-linolenic acids, followed by saturated (SFA) and MUFA (Table 2). Moreover, the ratio of PUFA/SFA and n6/ $\mathrm{n} 3$ were higher than 0.45 and lower than 4.0 , respectively for all the tested materials indicating a high nutritional value (Guil, Torija, Giménez, \& Rodriguez, 1996). Seed oils obtained with HE and CE1 methods showed lower $\mathrm{n} 6 / \mathrm{n} 3$ ratio values due to the higher content in $\alpha$-linolenic acid comparing to CE2 method.

Seed pre-treatments may have a beneficial effect on oil extraction yield and extraction process efficiency, although special attention should also be given on the composition of the obtained oils (Uquiche, Jeréz, \& Ortíz, 2008; Yoshida, Tomiyama, Hirakawa, \& Mizushina, 2006). In our study, the oil extraction efficiency and the effect of ultrasound-assisted and Soxhlet extraction methods on fatty acid composition of seeds and seedcakes were tested. The extraction for $8 \mathrm{~h}$ with a Soxhlet apparatus using hexane as a solvent gave the best results in terms of oil extraction yield for all the tested materials, except for the case of seedcakes obtained with CE2 method where no differences between the defatting methods were observed (Fig. 1b). Fatty acid composition was not significantly $(p>0.05)$ affected $(p \leq 0.05)$ by the applied defatting methods, following similar trends as shown in Table 2 for the same tested materials, and only slight fluctuations in fatty acids 
Table 2

Fatty acids composition (relative percentage, \%) of the studied purslane seeds, seedcakes and seed oils (mean \pm SD).

\begin{tabular}{|c|c|c|c|c|c|c|c|}
\hline & Seeds & Seedcake $(\mathrm{HE})^{\mathrm{a}}$ & Seedcake (CE1) & Seedcake (CE2) & Seed oils (HE) & Seed oils (CE1) & Seed oils (CE2) \\
\hline C6:0 & $0.011 \pm 0.001 c$ & $0.015 \pm 0.001 b$ & $0.025 \pm 0.001 \mathrm{a}$ & $0.009 \pm 0.001 \mathrm{~d}$ & nd & nd & nd \\
\hline C8:0 & $0.003 \pm 0.001 \mathrm{~d}$ & $0.008 \pm 0.001 c$ & $0.011 \pm 0.001 b$ & $0.012 \pm 0.001 \mathrm{a}$ & nd & nd & nd \\
\hline C10:0 & $0.002 \pm 0.001 d$ & $0.004 \pm 0.001 \mathrm{c}$ & $0.006 \pm 0.001 \mathrm{a}$ & $0.005 \pm 0.001 b$ & nd & nd & nd \\
\hline C12:0 & $0.014 \pm 0.001 \mathrm{~d}$ & $0.022 \pm 0.001 \mathrm{c}$ & $0.025 \pm 0.001 \mathrm{a}$ & $0.024 \pm 0.001 b$ & nd & nd & nd \\
\hline C14:0 & $0.056 \pm 0.002 \mathrm{e}$ & $0.064 \pm 0.003 \mathrm{~d}$ & $0.067 \pm 0.001 \mathrm{c}$ & $0.079 \pm 0.001 \mathrm{a}$ & $0.048 \pm 0.001 \mathrm{~g}$ & $0.053 \pm 0.001 \mathrm{f}$ & $0.071 \pm 0.002 b$ \\
\hline C15:0 & $0.033 \pm 0.001 d$ & $0.036 \pm 0.001 b$ & $0.035 \pm 0.001 \mathrm{c}$ & $0.041 \pm 0.001 \mathrm{a}$ & nd & nd & \\
\hline $\mathrm{C} 16: 0$ & $13.73 \pm 0.08 \mathrm{e}$ & $14.6 \pm 0.1 \mathrm{a}$ & $14.2 \pm 0.1 \mathrm{~b}$ & $14.2 \pm 0.2 \mathrm{~b}$ & $14.13 \pm 0.03 \mathrm{~d}$ & $14.18 \pm 0.04 c$ & $12.26 \pm 0.09 \mathrm{f}$ \\
\hline C16:1 & $0.102 \pm 0.001 \mathrm{~d}$ & $0.104 \pm 0.008 b$ & $0.102 \pm 0.001 \mathrm{~d}$ & $0.103 \pm 0.002 c$ & $0.085 \pm 0.003 \mathrm{e}$ & $0.085 \pm 0.002 \mathrm{e}$ & $0.11 \pm 0.01 \mathrm{a}$ \\
\hline $\mathrm{C} 17: 0$ & $0.110 \pm 0.001 \mathrm{~d}$ & $0.119 \pm 0.001 b$ & $0.120 \pm 0.004 a$ & $0.113 \pm 0.005 c$ & $0.098 \pm 0.001 \mathrm{e}$ & $0.097 \pm 0.003 f$ & $0.089 \pm 0.001 \mathrm{~g}$ \\
\hline C18:0 & $3.12 \pm 0.04 d$ & $3.14 \pm 0.01 c$ & $3.23 \pm 0.01 b$ & $3.25 \pm 0.02 \mathrm{a}$ & $3.078 \pm 0.006 \mathrm{f}$ & $3.10 \pm 0.01 \mathrm{e}$ & $3.07 \pm 0.01 \mathrm{f}$ \\
\hline C18:1n9 & $12.63 \pm 0.05 b$ & $12.19 \pm 0.07 \mathrm{~d}$ & $12.84 \pm 0.02 \mathrm{a}$ & $12.4 \pm 0.2 \mathrm{c}$ & $5.78 \pm 0.01 \mathrm{f}$ & $5.78 \pm 0.01 \mathrm{f}$ & $8.85 \pm 0.02 \mathrm{e}$ \\
\hline C18:2n6 & $33.80 \pm 0.01 \mathrm{~g}$ & $34.51 \pm 0.05 \mathrm{f}$ & $34.61 \pm 0.06 \mathrm{e}$ & $34.74 \pm 0.02 \mathrm{~d}$ & $35.44 \pm 0.01 b$ & $35.13 \pm 0.03 c$ & $49.77 \pm 0.08 \mathrm{a}$ \\
\hline $\mathrm{C} 18: 3 \mathrm{n} 3$ & $34.64 \pm 0.01 c$ & $33.4 \pm 0.1 \mathrm{~d}$ & $32.83 \pm 0.06 \mathrm{f}$ & $33.02 \pm 0.01 \mathrm{e}$ & $39.67 \pm 0.03 a$ & $39.57 \pm 0.05 b$ & $24.18 \pm 0.05 \mathrm{~g}$ \\
\hline C20:0 & $0.69 \pm 0.01 c$ & $0.69 \pm 0.03 c$ & $0.74 \pm 0.01 b$ & $0.75 \pm 0.01 \mathrm{a}$ & $0.631 \pm 0.001 \mathrm{e}$ & $0.645 \pm 0.005 d$ & $0.454 \pm 0.005 f$ \\
\hline $\mathrm{C} 20: 1$ & $0.124 \pm 0.004 c$ & $0.15 \pm 0.01 \mathrm{a}$ & $0.109 \pm 0.003 \mathrm{e}$ & $0.136 \pm 0.004 \mathrm{~b}$ & $0.094 \pm 0.003 \mathrm{~g}$ & $0.096 \pm 0.001 \mathrm{f}$ & $0.112 \pm 0.001 \mathrm{~d}$ \\
\hline $\mathrm{C} 20: 3 \mathrm{n} 3+\mathrm{C} 21: 0$ & $0.037 \pm 0.001 b$ & $0.018 \pm 0.001 \mathrm{~d}$ & $0.051 \pm 0.001 \mathrm{a}$ & $0.021 \pm 0.001 \mathrm{c}$ & nd & nd & nd \\
\hline C20:5n3 & $0.004 \pm 0.001 c$ & $0.004 \pm 0.001 c$ & $0.006 \pm 0.001 b$ & $0.008 \pm 0.001 \mathrm{a}$ & nd & nd & nd \\
\hline $\mathrm{C} 22: 0$ & $0.78 \pm 0.01 \mathrm{~d}$ & $0.85 \pm 0.02 c$ & $0.91 \pm 0.02 b$ & $0.94 \pm 0.01 \mathrm{a}$ & $0.257 \pm 0.001 \mathrm{e}$ & $0.26 \pm 0.01 \mathrm{e}$ & $0.138 \pm 0.002 \mathrm{f}$ \\
\hline $\mathrm{C} 22: 2$ & nd & nd & nd & nd & $0.43 \pm 0.03 c$ & $0.44 \pm 0.02 b$ & $0.690 \pm 0.003 \mathrm{a}$ \\
\hline $\mathrm{C} 23: 0$ & $0.034 \pm 0.002 b$ & $0.029 \pm 0.001 \mathrm{c}$ & $0.028 \pm 0.001 \mathrm{~d}$ & $0.035 \pm 0.001 \mathrm{a}$ & $0.26 \pm 0.01 \mathrm{f}$ & $0.27 \pm 0.02 \mathrm{e}$ & $0.218 \pm 0.009 \mathrm{~g}$ \\
\hline $\mathrm{C} 24: 0$ & $0.089 \pm 0.004 c$ & $0.091 \pm 0.001 b$ & $0.108 \pm 0.001 \mathrm{a}$ & $0.089 \pm 0.001 c$ & nd & nd & nd \\
\hline Total SFA (\% of total FA) & $18.66 \pm 0.05 d$ & $19.62 \pm 0.09 a$ & $19.5 \pm 0.1 b$ & $19.6 \pm 0.2 \mathrm{a}$ & $18.51 \pm 0.03 \mathrm{e}$ & $18.71 \pm 0.07 \mathrm{c}$ & $16.3 \pm 0.1 \mathrm{f}$ \\
\hline Total MUFA (\% of total FA) & $12.86 \pm 0.06 \mathrm{~b}$ & $12.45 \pm 0.09 \mathrm{~d}$ & $13.05 \pm 0.02 \mathrm{a}$ & $12.7 \pm 0.2 \mathrm{c}$ & $5.96 \pm 0.01 \mathrm{f}$ & $5.96 \pm 0.01 \mathrm{f}$ & $9.07 \pm 0.03 \mathrm{e}$ \\
\hline Total PUFA ( $\%$ of total FA) & $68.49 \pm 0.01 \mathrm{~d}$ & $67.9 \pm 0.2 \mathrm{e}$ & $67.5 \pm 0.1 \mathrm{f}$ & $67.78 \pm 0.02$ & $75.53 \pm 0.02 \mathrm{a}$ & $75.33 \pm 0.06 b$ & $74.6 \pm 0.1 c$ \\
\hline PUFA/SFA & $3.67 \pm 0.03 d$ & $3.46 \pm 0.05 \mathrm{e}$ & $3.46 \pm 0.1 \mathrm{e}$ & $3.46 \pm 0.01$ & $4.09 \pm 0.02 b$ & $4.03 \pm 0.06 c$ & $4.58 \pm 0.1 \mathrm{a}$ \\
\hline $\mathrm{n} 6 / \mathrm{n} 3^{* *}$ & $0.97 \pm 0.01 \mathrm{~d}$ & $1.03 \pm 0.05 c$ & $1.05 \pm 0.06 \mathrm{~b}$ & $1.05 \pm 0.02 \mathrm{~b}$ & $0.90 \pm 0.01 \mathrm{e}$ & $0.90 \pm 0.03 e$ & $2.09 \pm 0.08 \mathrm{a}$ \\
\hline
\end{tabular}

${ }^{a}$ HE: Hot extraction; CE1: Cold extraction 1; CE2: Cold extraction 2; nd: not detected.

content were observed (Table S1; Supplementary Material). Similarly to this study, Samaram, Mirhosseini, Tan, and Ghazali (2013) reported differences in oil extraction yield for papaya seeds when ultrasoundassisted and solvent extraction were implemented without fatty acids composition being affected. In addition, in the same study it was suggested that prolonging extraction time up to $12 \mathrm{~h}$ increased oil extraction yield for solvent extraction, whereas ultrasound-assisted extraction resulted in similar to solvent extraction yields in only $30 \mathrm{~min}$ (Samaram et al., 2013). Moreover, Gutte, Sahoo, and Ranveer (2015) studied the effect of ultrasounds treatment on flaxseed oil and reported an increase in oil extraction yield by $11.5 \%$ without significant effects on the content of $\alpha$-linolenic acid. However, they mentioned that optimization of the extraction process parameters is needed in order to increase oil extraction yields (Gutte et al., 2015). This efficiency of ultrasound-assisted extraction could be attributed to acoustic cavitation which may disrupt cell walls as well as to agitation of solvent allowing the better penetration of solvents into seeds (Chemat, Vian, \& Cravotto, 2012).

Total phenolic compounds (TPC) content of the studied materials is presented in Table 3. Seedcakes contained higher amounts of TPC
Table 3

Total phenolic compounds of the studied purslane seeds, seedcakes and seed oils expressed as $\mathrm{mg}$ of Gallic acid equivalents (mean $\pm \mathrm{SD}$ ).

\begin{tabular}{ll}
\hline & Folin-ciocalteu assay (mg GAE/g extract) \\
\hline Seedcake (HE) & $25.9 \pm 0.6 \mathrm{~b}$ \\
Seedcake (CE1) & $23.8 \pm 0.4 \mathrm{c}$ \\
Seedcake (CE2) & $32.63 \pm 0.02 \mathrm{a}$ \\
Seeds & $21.0 \pm 0.5 \mathrm{~d}$ \\
& Folin-ciocalteu assay (mg GAE/g oil) \\
Seed oil (HE) & $0.23 \pm 0.01 \mathrm{a}$ \\
Seed oil (CE1) & $0.15 \pm 0.01 \mathrm{~b}$ \\
Seed oil (CE2) & $0.22 \pm 0.01 \mathrm{a}$
\end{tabular}

Different Latin letters in the same column refer to significant differences according to Tukey's HSD test $(p \leq 0.05)$.

${ }^{a}$ HE: Hot extraction; CE1: Cold extraction 1; CE2: Cold extraction 2.

comparing to seeds, especially seedcakes obtained from CE2 method which had the highest TPC content ( $32.63 \mathrm{mg} \mathrm{GAE} / \mathrm{g}$ extract), indicating the potential use of purslane seed oil byproducts as sources of bioactive compounds. TPC content in seed oils was also varied with HE

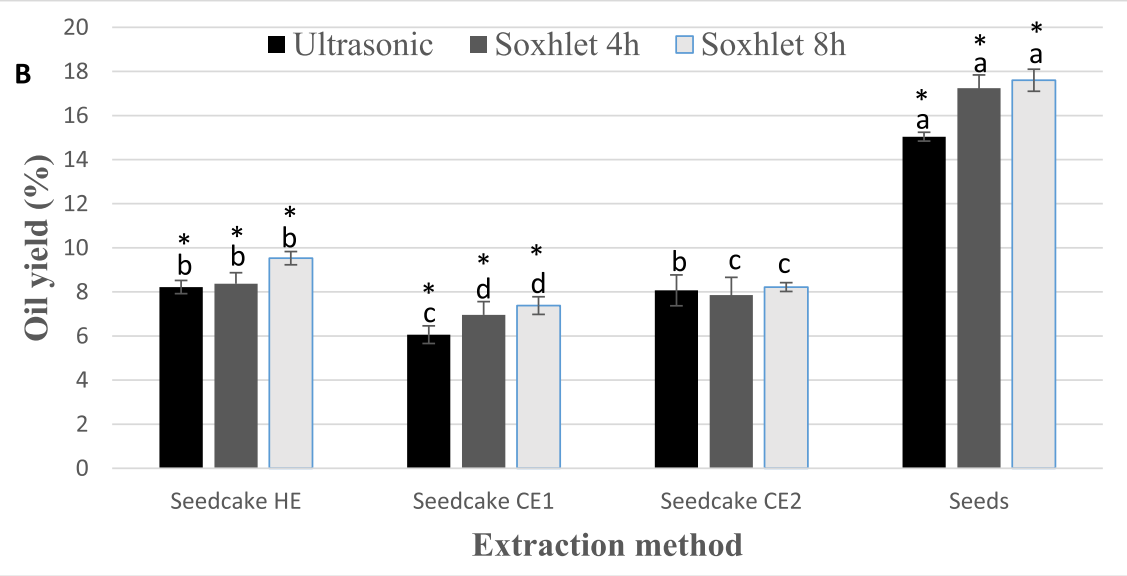

Fig. 1B. Oil yield (\%) in relation to extraction and defatting method. Each extraction and defatting method is compared with raw seeds which is considered to contain $100 \%$ of oil. Different Latin letters indicate differences between the tested materials for the same defatting method according to Tukey's HSD test $(p \leq 0.05)$. The asterisk symbol indicates differences between the defatting methods for the same material according to Tukey's HSD test ( $p \leq 0.05)$.

${ }^{¥} \mathrm{HE}$ : Hot extraction; CE1: Cold extraction 1 ; CE2: Cold extraction 2 . 
Table 4

Antibacterial activity of the studied purslane seeds, seedcakes and seed oils (MIC and MBC mg/mL).

\begin{tabular}{|c|c|c|c|c|c|c|c|c|c|c|}
\hline \multirow[t]{2}{*}{ Compounds } & \multicolumn{2}{|c|}{ S. aureus (ATCC 11632) } & \multicolumn{2}{|c|}{ E. coli (food isolate) } & \multicolumn{2}{|c|}{ M. flavus (ATCC 10240) } & \multicolumn{2}{|c|}{ B. cereus (food isolate) } & \multicolumn{2}{|c|}{ L. monocytogenes (NCTC 7973) } \\
\hline & MIC & MBC & MIC & MBC & MIC & MBC & MIC & MBC & MIC & $\mathrm{MBC}$ \\
\hline Streptomycin (positive control) & 0.006 & 0.012 & 0.10 & 0.20 & 0.20 & 0.30 & 0.10 & 0.20 & 0.20 & 0.30 \\
\hline Ampicillin (positive control) & 0.012 & 0.025 & 0.20 & - & 0.30 & 0.30 & 0.25 & 0.40 & 0.40 & 0.50 \\
\hline Seedcake $(\mathrm{HE})^{\mathrm{a}}$ & 2.00 & 4.00 & 4.00 & 8.00 & 2.00 & 4.00 & 1.00 & 2.00 & 4.00 & 8.00 \\
\hline Seedcake (CE1) & 4.00 & 8.00 & 4.00 & 8.00 & 2.00 & 4.00 & 1.00 & 2.00 & 4.00 & 8.00 \\
\hline Seedcake (CE2) & 2.00 & 4.00 & 4.00 & 8.00 & 2.00 & 4.00 & 1.00 & 2.00 & 4.00 & 8.00 \\
\hline Seeds & 1.00 & 2.00 & 1.00 & 2.00 & 0.25 & 0.50 & 0.50 & 1.00 & 1.00 & 2.00 \\
\hline Seed oil (HE) & 4.00 & 8.00 & 2.00 & 4.00 & 2.00 & 4.00 & 2.00 & 4.00 & 2.00 & 4.00 \\
\hline Seed oil (CE1) & 4.00 & 8.00 & 2.00 & 4.00 & 2.00 & 4.00 & 2.00 & 4.00 & 4.00 & 8.00 \\
\hline Seed oil (CE2) & 2.00 & 4.00 & 1.00 & 2.00 & 2.00 & 4.00 & 1.00 & 2.00 & 2.00 & 4.00 \\
\hline
\end{tabular}

-: No activity; MIC: Minimal inhibitory concentration; MBC: Minimal bactericidal concentration.

${ }^{a}$ HE: Hot extraction; CE1: Cold extraction 1; CE2: Cold extraction 2.

and CE2 methods having the highest content $(0.23$ and $0.22 \mathrm{mg} \mathrm{GAE} / \mathrm{g}$ oil). Sodeifian et al. (2018) reported a higher TPC content in purslane seed oil obtained with supercritical fluid and solvent extraction (1.73 and $1.67 \mathrm{mg} \mathrm{GAE} / \mathrm{g}$ oil, respectively), whereas Delfan-Hosseini et al. (2017) found TPC values similar to our study for solvent-extracted seed oils of purslane ( $0.19 \mathrm{mg} \mathrm{GAE} / \mathrm{g}$ oil). Moreover, in a previous studies of our team with cardoon seed oils obtained with two methods corresponding to HE and CE1 methods of the present study, TPC content of HE method was also higher than that of CE1 method (Petropoulos et al., 2018). These differences in the literature reports could be attributed to different extraction parameters, as well as to genotypic differences of the studied materials.

Antibacterial and antifungal activity of purslane seeds, seed oils and seedcakes are presented in Tables 4 and 5. All the studied materials showed low efficacy against the tested bacteria in comparison to the positive controls (streptomycin and ampicillin) (Table 4). However, it worth's mentioning the higher antibacterial activity of seeds comparing to seedcakes and seed oils. Similarly, positive controls (bifonazole and ketoconazole) had a higher antifungal activity than the studied materials, while seeds and seedcakes were more efficient against Aspergillus niger, A. versicolor, and Trichoderma viride comparing to seed oils (Table 5). According to Tayel et al. (2018), purslane seed extracts showed moderate antibacterial activity against normal strains of Staphylococcus aureus and no activity against methicillin resistant strains, while Bakkiyaraj and Pandiyaraj (2011) reported the antibacterial activity of purslane leaf extracts against Bacillus subtilis, S. aureus and Pseudomonas aeruginosa attributed to the phytochemicals content of plant tissues.

Regarding the cytotoxicity of seeds, seed oil and seedcakes against PLP2 cells, the results showed no cytotoxic effects for seedcakes, whereas seed oils from CE1 had the lowest $\mathrm{GI}_{50}$ values
Table 6

Cytotoxicity of the studied purslane seeds, seedcakes and seed oils ( $\mathrm{GI}_{50}$ values $\mu \mathrm{g} / \mathrm{mL})$.

\begin{tabular}{ll}
\hline & Hepatotoxicity PLP2 (non-tumor cells) \\
\hline Purslane seeds & $259.7 \pm 9.5 \mathrm{a}$ \\
Seedcake (HE) $^{\mathrm{a}}$ & $>400$ \\
Seedcake (CE 1) & $>400$ \\
Seedcake (CE 2) & $>400$ \\
Seed oil (HE) & $204 \pm 9 \mathrm{c}$ \\
Seed oil (CE1) & $204.7 \pm 13.7 \mathrm{c}$ \\
Seed oil (CE2) & $221 \pm 15 \mathrm{~b}$ \\
\hline
\end{tabular}

Different Latin letters in the same column refer to significant differences between seedcakes and seeds according to Tukey's HSD test $(p \leq 0.05)$.

${ }^{\text {a }}$ HE: Hot extraction; CE1: Cold extraction 1; CE2: Cold extraction 2.

$(204.7 \pm 13.7 \mu \mathrm{g} / \mathrm{mL})$, followed by HE $(204 \pm 9 \mu \mathrm{g} / \mathrm{mL})$, CE2 $(221 \pm 15 \mu \mathrm{g} / \mathrm{mL})$ and seeds $(259.7 \pm 9.5 \mu \mathrm{g} / \mathrm{mL}$ ) (Table 6). To the best of our knowledge, no reports regarding the cytotoxic effects of purslane seeds and seed products are available in the literature, since most of the existing reports refer to the aerial parts of the plant (Lei, Li, Liu, Zhang, \& Liu, 2015; Lim \& Quah, 2007). According to Eidi, Mortazavi, Moghadam, and Mardani (2015) and Farshori et al. (2014) who studied the cytotoxic effects of purslane aerial parts extract, the potency of extracts could be attributed to various phytochemicals present in plant tissues, including seeds, seed oils and seedcakes.

\section{Conclusion}

In conclusion, the tested materials proved to be promising sources of linoleic and $\alpha$-linolenic acid, whereas none of the tested materials

Table 5

Antifungal activity of the studied purslane seeds, seedcakes and seed oils (MIC and MFC mg/mL).

\begin{tabular}{|c|c|c|c|c|c|c|c|c|c|c|}
\hline \multirow[t]{2}{*}{ Compounds } & \multicolumn{2}{|c|}{$\begin{array}{l}\text { Aspergillus fumigatus (ATCC } \\
\text { 9197) }\end{array}$} & \multicolumn{2}{|c|}{$\begin{array}{l}\text { Aspergillus niger (ATCC } \\
6275 \text { ) }\end{array}$} & \multicolumn{2}{|c|}{$\begin{array}{l}\text { Aspergillus versicolor (ATCC } \\
\text { 11730) }\end{array}$} & \multicolumn{2}{|c|}{$\begin{array}{l}\text { Penicillium funiculosum (ATCC } \\
\text { 36839) }\end{array}$} & \multicolumn{2}{|c|}{$\begin{array}{l}\text { Trichoderma viride (IAM } \\
\text { 5061) }\end{array}$} \\
\hline & MIC & $\mathrm{MBC}$ & MIC & $\mathrm{MBC}$ & MIC & $\mathrm{MBC}$ & MIC & MBC & MIC & $\mathrm{MBC}$ \\
\hline Bifonazole (positive control) & 0.15 & 0.20 & 0.15 & 0.20 & 0.13 & 0.17 & 0.20 & 0.25 & 0.10 & 0.20 \\
\hline $\begin{array}{l}\text { Ketoconazole (positive } \\
\text { control) }\end{array}$ & 0.20 & 0.50 & 0.20 & 0.50 & 0.20 & 0.47 & 0.20 & 0.50 & 0.20 & 0.30 \\
\hline Seedcake $(\mathrm{HE})^{\mathrm{a}}$ & 2.00 & 4.00 & 1.00 & 2.00 & 0.50 & 1.00 & 1.00 & 2.00 & 0.50 & 1.00 \\
\hline Seedcake (CE1) & 1.00 & 2.00 & 1.00 & 2.00 & 0.50 & 1.00 & 0.50 & 1.00 & 0.50 & 1.00 \\
\hline Seedcake (CE2) & 0.50 & 1.00 & 1.00 & 2.00 & 0.50 & 1.00 & 1.00 & 2.00 & 0.50 & 1.00 \\
\hline Seeds & 0.50 & 1.00 & 1.00 & 2.00 & 0.50 & 1.00 & 1.00 & 2.00 & 0.50 & 1.00 \\
\hline Seed oil (HE) & 2.00 & 4.00 & 4.00 & 8.00 & 2.00 & 4.00 & 2.00 & 4.00 & 4.00 & 8.00 \\
\hline Seed oil (CE1) & 2.00 & 4.00 & 2.00 & 4.00 & 2.00 & 4.00 & 1.00 & 2.00 & 1.00 & 2.00 \\
\hline Seed oil (CE2) & 2.00 & 4.00 & 2.00 & 4.00 & 4.00 & 8.00 & 2.00 & 4.00 & 4.00 & 8.00 \\
\hline
\end{tabular}

-: No activity; MIC: Minimal inhibitory concentration; MBC: Minimal bactericidal concentration; MFC: Minimal fungicidal concentration.

a HE: Hot extraction; CE1: Cold extraction 1; CE2: Cold extraction 2. 
showed good results in terms of antibacterial and antifungal properties. In addition, the results of the present study demonstrated that the application of different mechanical extraction methods may have a significant effect $(p \leq 0.05)$ on oil extraction yield from purslane seeds, while a significant effect $(p \leq 0.05)$ of mechanical extraction methods on omega- 6 and omega- 3 fatty acids content of seed oils was also observed. Finally, considering the very small size of purslane seeds further research is needed to study the various parameters involved in the extraction process that could affect not only oil yield but also oil quality and chemical composition of the obtained oils and byproducts.

\section{CRediT authorship contribution statement}

Spyridon A. Petropoulos: Supervision, Writing - original draft, Writing - review \& editing. Ângela Fernandes: Formal analysis, Data curation, Methodology. Dimitrios A. Arampatzis: Formal analysis. Nikolaos G. Tsiropoulos: Supervision. Jovana Petrović: Formal analysis. Marina Soković: Supervision. Lillian Barros: Writing - review \& editing, Writing - original draft, Formal analysis, Data curation, Methodology. Isabel C.F.R. Ferreira: Funding acquisition, Supervision, Writing - review \& editing, Project administration.

\section{Declaration of competing interest}

The authors declare that they have no known competing financial interests or personal relationships that could have appeared to influence the work reported in this paper.

\section{Acknowledgements}

We are thankful to Prof. Theofanis Gemtos, head of the Laboratory of Agricultural Machinery, University of Thessaly, Greece, for providing the equipment and technical assistance for hot extraction of seed oils. We are also thankful to Mr. Tsolakidis C. (Giachanas - Cold Pressed Seed Oils S.A.; Evros, Greece) for providing the equipment and technical assistance for cold extraction of seed oils. The authors are also grateful to the Foundation for Science and Technology (FCT, Portugal) and FEDER under Programme PT2020 for financial support to CIMO (UID/ AGR/00690/2019). L. Barros and A. Fernandes would like to thank the national funding by FCT, P.I., through the institutional scientific employment program-contract for their contracts.

\section{Appendix A. Supplementary data}

Supplementary data to this article can be found online at https:// doi.org/10.1016/j.lwt.2020.109099.

Different Latin letters in the same row refer to significant differences between seeds, seedcakes, and seed oils according to Tukey's HSD test $(p \leq 0.05)$.

C6:0 caproic acid; C8:0 caprylic acid; C10:0 capric acid; C12:0 lauric acid; C14:0 myristic acid; C15:0 pentadecanoic acid; C16:0 palmitic acid; C16:1 palmitoleic acid; C17:0 heptadecanoic acid; C18:0 stearic acid, C18:1n9c oleic acid, C18:2n6c linoleic acid, C18:3n $\alpha$ linolenic acid, C20:0 arachidic acid; C20:1 eicosenoic acid; C20:3n3 eicosatrienoic acid; C20:5n3 eicosapentaenoic acid; C21:0 heneicosylic acid; C22:0 behenic acid; C22:2 docosadienoic acid; C23:0 tricosylic acid; C24:0 lignoceric acid; SFA: saturated fatty acids; MUFA: monounsaturated fatty acids; PUFA: polyunsaturated fatty acids; n6/n3: ratio of omega-6/omega-3 fatty acids.

\section{References}

Abreu, R. M. V., Ferreira, I. C. F. R., Calhelha, R. C., Lima, R. T., Vasconcelos, M. H., Adega, F., et al. (2011). Anti-hepatocellular carcinoma activity using human HepG2 cells and hepatotoxicity of 6 -substituted methyl 3-aminothieno[3,2-b]pyridine-2carboxylate derivatives: In vitro evaluation, cell cycle analysis and QSAR studies.
European Journal of Medicinal Chemistry, 46(12), 5800-5806. https://doi.org/10. 1016/j.ejmech.2011.09.029.

Andre, C., Buesen, R., Riffle, B., Wandelt, C., Sottosanto, J. B., Marxfeld, H., et al. (2019). Safety assessment of EPA + DHA canola oil by fatty acid profile comparison to various edible oils and fat-containing foods and a 28-day repeated dose toxicity study in rats. Food and Chemical Toxicology, 124(September 2018), 168-181. https://doi.org/10. 1016/j.fct.2018.11.042.

AOAC (2016). Official methods of analysis of AOAC International. In W. Horwitz, \& G. Latimer (Eds.). Official methods of analysis of AOAC international(20th ed.). Gaithersburg: MD: AOAC International.

Arampatzis, D. A., Karkanis, A. C., \& Tsiropoulos, N. G. (2019). Silymarin content and antioxidant activity of seeds of wild Silybum marianum populations growing in Greece. Annals of Applied Biology, 174(1), 61-73. https://doi.org/10.1111/aab. 12470.

Bakkiyaraj, S., \& Pandiyaraj, A. S. (2011). Evaluation of potential antimicrobial activity of some medicinal plants against common food-borne pathogenic microorganism. International Journal of Pharma Bio Sciences, 2(2), 484-491.

Barros, L., Pereira, E., Calhelha, R. C., Dueñas, M., Carvalho, A. M., Santos-Buelga, C., et al. (2013). Bioactivity and chemical characterization in hydrophilic and lipophilic compounds of Chenopodium ambrosioides L. Journal of Functional Foods, 5(4), 1732-1740. https://doi.org/10.1016/j.jff.2013.07.019.

Barros, L., Pereira, C., \& Ferreira, I. C. F. R. (2013). Optimized analysis of organic acids in edible mushrooms from Portugal by ultra-fast liquid chromatography and photodiode array detection. Food Analytical Methods, 6(1), 309-316. https://doi.org/10.1007/ s12161-012-9443-1.

Bosi, G., Guarrera, P. M., Rinaldi, R., \& Mazzanti, M. B. (2009). Ethnobotany of purslane (Portulaca oleracea L.) in Italy and morphobiometric analyses of seeds from archaeological sites in the Emilia Romagna Region (Northern Italy). In J.-P. Morel, \& A. M. Mercuri (Eds.). Plants and culture: Seeds of the cultural heritage of Europe (pp. 129139). Bari: Edipuglia.

Calder, P. C. (2018). Very long-chain n-3 fatty acids and human health: Fact, fiction and the future. Proceedings of the Nutrition Society, 77(1), 52-72. https://doi.org/10.1017/ S0029665117003950.

Chemat, F., Vian, M. A., \& Cravotto, G. (2012). Green extraction of natural products: Concept and principles. International Journal of Molecular Sciences, 13(7), 8615-8627. https://doi.org/10.3390/ijms13078615.

Delfan-Hosseini, S., Nayebzadeh, K., Mirmoghtadaie, L., Kavosi, M., \& Hosseini, S. M. (2017). Effect of extraction process on composition, oxidative stability and rheological properties of purslane seed oil. Food Chemistry, 222, 61-66. https://doi.org/10. 1016/j.foodchem.2016.11.150.

Dias, M. I., Barros, L., Dueñas, M., Pereira, E., Carvalho, A. M., Alves, R. C., et al. (2013). Chemical composition of wild and commercial Achillea millefolium L. and bioactivity of the methanolic extract, infusion and decoction. Food Chemistry, 141(4), 4152-4160. https://doi.org/10.1016/j.foodchem.2013.07.018.

Dubois, V., Breton, S., Linder, M., Fanni, J., \& Parmentier, M. (2007). Fatty acid profiles of 80 vegetable oils with regard to their nutritional potential. European Journal of Lipid Science and Technology, 109(7), 710-732. https://doi.org/10.1002/ejlt.200700040.

Eidi, A., Mortazavi, P., Moghadam, J. Z., \& Mardani, P. M. (2015). Hepatoprotective effects of Portulaca oleracea extract against $\mathrm{CCl} 4$-induced damage in rats. Pharmaceutical Biology, 53(7), 1042-1051. https://doi.org/10.3109/13880209.2014. 957783.

FAO (1998a). Chapter 2: Methods of food analysis. Available in (september 2019)http:// www.fao.org/3/Y5022E/y5022e03.htm\#fn6.

FAO (1998b). Chapter 3: Calculation of the energy content of foods - energy conversion factors. Available in (September 2019)http://www.fao.org/3/y5022e/y5022e04.htm.

Farshori, N. N., Al-Sheddi, E. S., Al-Oqail, M. M., Musarrat, J., Al-Khedhairy, A. A., \& Siddiqui, M. A. (2014). Cytotoxicity assessments of Portulaca oleracea and Petroselinum sativum seed extracts on human hepatocellular carcinoma cells (HepG2). Asian Pacific Journal of Cancer Prevention, 15(16), 6633-6638. https://doi.org/10. 7314/APJCP.2014.15.16.6633.

Ghamari, H., Shafagh Kolvanagh, J., Sabaghpour, S. H., \& Dabbagh Mohammadi Nassab, A. (2016). The effect of intercropping and nitroxin biofertilizer on yield components and relative yield total of purslane (Portulaca oleracea L.) and dragon's head (Lallemantia iberica Fisch. \& C.A. Mey). Notulae Scientia Biologicae, 8(4), 472-476. https://doi.org/10.15835/nsb849936.

Gheysen, L., Lagae, N., Devaere, J., Goiris, K., Goos, P., Bernaerts, T., et al. (2019). Impact of Nannochloropsis sp. dosage form on the oxidative stability of n-3 LC-PUFA enriched tomato purees. Food Chemistry, 279, 389-400. https://doi.org/10.1016/j.foodchem. 2018.12.026 August 2018.

Gonnella, M., National, I., Charfeddine, M., Agricultural, C. R. A., Universit, G. C., Universit, P. S., et al. (2010). Purslane: A review of its potential for health and agricultural aspects. The European Journal of Plant Science and Biotechnology, 4(1), $131-136$.

Guil-Guerrero, J. L., \& Rodríguez-García, I. (1999). Lipids classes, fatty acids and carotenes of the leaves of six edible wild plants. European Food Research and Technology, 209(5), 313-316. https://doi.org/10.1007/s002170050501.

Guil, J. L., Torija, M. E., Giménez, J. J., \& Rodriguez, I. (1996). Identification of fatty acids in edible wild plants by gas chromatography. Journal of Chromatography A, 719, 229-235. https://doi.org/10.1007/s12161-008-9063-y.

Gunenc, A., Rowland, O., Xu, H., Marangoni, A., \& Hosseinian, F. (2019). Portulaca oleracea seeds as a novel source of alkylresorcinols and its phenolic profiles during germination. Lebensmittel-Wissenschaft und -Technologie- Food Science and Technology, 101, 246-250. https://doi.org/10.1016/j.lwt.2018.10.075.

Gutte, K. B., Sahoo, A. K., \& Ranveer, R. C. (2015). Effect of ultrasonic treatment on extraction and fatty acid profile of flaxseed oil. OCL, 22(6), D606. https://doi.org/10. $1051 / \mathrm{ocl} / 2015038$. 
Hill, L. M., Morley-Smith, E. R., \& Rawsthorne, S. (2003). Metabolism of sugars in the endosperm of developing seeds of oilseed rape. Plant Physiology, 131(1), 228-236. https://doi.org/10.1104/pp.010868.

Ionescu, M., Voicu, G., Biris, S. S., Ungureanu, N., Vladut, V., Voicea, I., et al. (2015). An oil expression process using screw presses with strainers oil outlet. Symposium "actual tasks on agricultural engineering" (pp. 513-524). . https://doi.org/10.13140/RG.2.1. 4147.4089 Opatija.

Ionescu, M., Voicu, G., Sorin-Stefan, B., Covaliu, C., Dincă, M., \& Ungureanu, N. (2014). Parameters influencing the screw pressing process of oilseed materials. 2nd international conference on thermal equipment (pp. 243-248). Renewable Energy and Rural Development.

Jalali Mousavi, S. R., Niazmand, R., \& Shahidi Noghabi, M. (2015). Antioxidant activity of purslane (Portulaca oleracea L.) seed hydro-alcoholic extract on the stability of soybean oil. Journal of Agricultural Science and Technology A, 17(6), 1473-1480.

Karkanis, A., Ntatsi, G., Alemardan, A., Petropoulos, S., \& Bilalis, D. (2019). Interference of weeds in vegetable crop cultivation, in the changing climate of Southern Europe with emphasis on drought and elevated temperatures: A review. The Journal of Agricultural Science, 156, 1175-1185. https://doi.org/10.1017/ S0021859619000108.

Kavosi, M., Mohammadi, A., Shojaee-Aliabadi, S., Khaksar, R., \& Hosseini, S. M. (2018). Characterization and oxidative stability of purslane seed oil microencapsulated in yeast cells biocapsules. Journal of the Science of Food and Agriculture, 98(7), 2490-2497. https://doi.org/10.1002/jsfa.8696.

Kim, H. U., Lee, K. R., Jeon, I., Jung, H. E., Heo, J. B., Kim, T. Y., et al. (2019). Fatty acid composition and oil content of seeds from perilla (Perilla frutescens (L.) var. frutescens) germplasm of Republic of Korea. Genetic Resources and Crop Evolution, 66(7), 1615-1624. https://doi.org/10.1007/s10722-019-00803-8.

Lei, X., Li, J., Liu, B., Zhang, N., \& Liu, H. (2015). Separation and identification of four new compounds with antibacterial activity from Portulaca oleracea L. Molecules, 20(9), 16375-16387. https://doi.org/10.3390/molecules200916375.

Lim, Y. Y., \& Quah, E. P. L. (2007). Antioxidant properties of different cultivars of Portulaca oleracea. Food Chemistry, 103(3), 734-740. https://doi.org/10.1016/j. foodchem.2006.09.025.

Mousavi, S. R. J., \& Niazmand, R. (2017). Fatty acids composition and oxidation kinetic parameters of purslane (Portulaca oleracea) seed oil. Agricultural Research, 6(4), 421-426. https://doi.org/10.1007/s40003-017-0271-9.

Nazeam, J. A., El-Hefnawy, H. M., Omran, G., \& Singab, A. N. (2018). Chemical profile and antihyperlipidemic effect of Portulaca oleracea L. seeds in streptozotocin-induced diabetic rats. Natural Product Research, 32(12), 1484-1488. https://doi.org/10.1080/ 14786419.2017.1353507.

Obodai, M., Mensah, D. L. N., Fernandes, Â., Kortei, N. K., Dzomeku, M., Teegarden, M., et al. (2017). Chemical characterization and antioxidant potential of wild ganoderma species from Ghana. Molecules, 22(2), 1-18. https://doi.org/10.3390/ molecules22020196.

Oliveira, I., Valentão, P., Lopes, R., Andrade, P. B., Bento, A., \& Pereira, J. A. (2009). Phytochemical characterization and radical scavenging activity of Portulaca oleraceae L. leaves and stems. Microchemical Journal, 92(2), 129-134. https://doi.org/10.1016/ j.microc.2009.02.006.

Palaniswamy, U. R., McAvoy, R. J., \& Bible, B. (2004). Oxalic acid concentrations in purslane (Portulaca oleraceae L.) is altered by the stage of harvest and the nitrate to ammonium ratios in hydroponics. Scientia Horticulturae, 629(3), 299-305. https:// doi.org/10.1016/j.scienta.2004.01.006.

Perona, J. S., Garcia-Rodrigue, S., \& Castellano, J. M. (2018). Plants as alternative sources of n-3 polyunsaturated fatty acids. Polyunsaturated fatty acids (PUFAs): Food sources, health effects and significance in biochemistry (pp. 187-228). . Retrieved from https:// www.scopus.com/inward/record.uri? eid =2-s2.0-85058164497\& \&partnerID $=40$ \& md5 = cbc9297a8d3908b301a8c5b74b1804a0

Petropoulos, S. A., Fernandes, Â., Barros, L., Ciric, A., Sokovic, M., \& Ferreira, I. C. F. R. (2017). The chemical composition, nutritional value and antimicrobial properties of Abelmoschus esculentus seeds. Food \& Function, 8, 4733-4743. https://doi.org/10. 1039/c7fo01446e.

Petropoulos, S. A., Fernandes, Â., Calhelha, R. C., Danalatos, N., Barros, L., \& Ferreira, I. C. F. R. (2018). How extraction method affects yield, fatty acids composition and bioactive properties of cardoon seed oil? Industrial Crops and Products, 124(June),
459-465. https://doi.org/10.1016/j.indcrop.2018.08.027.

Petropoulos, S., Fernandes, Â., Pereira, C., Tzortzakis, N., Vaz, J., Soković, M., et al. (2019). Bioactivities, chemical composition and nutritional value of Cynara cardunculus L. seeds. Food Chemistry, 289(March), 404-412. https://doi.org/10.1016/j foodchem.2019.03.066.

Petropoulos, S., Karkanis, A., Fernandes, Â., Barros, L., Ferreira, I. C. F. R., Ntatsi, G., et al. (2015). Chemical composition and yield of six genotypes of common purslane (Portulaca oleracea L.): An alternative source of omega-3 fatty acids. Plant Foods for Human Nutrition, 70(4), 420-426. https://doi.org/10.1007/s11130-015-0511-8.

Petropoulos, S. A., Karkanis, A., Martins, N., \& Ferreira, I. C. F. R. (2016). Phytochemical composition and bioactive compounds of common purslane (Portulaca oleracea L.) as affected by crop management practices. Trends in Food Science \& Technology, 55, 1-10. https://doi.org/10.1016/j.tifs.2016.06.010.

Saleh, I. A., Vinatoru, M., Mason, T. J., Abdel-Azim, N. S., Aboutabl, E. A., \& Hammouda, F. M. (2015). Ultrasonic-assisted extraction and conventional extraction of silymarin from Silybum marianum seeds; A comparison. Research Journal of Pharmaceutical, Biological and Chemical Sciences, 6(2), 709-717.

Salem, N., \& Eggersdorfer, M. (2015). Is the world supply of omega-3 fatty acids adequate for optimal human nutrition? Current Opinion in Clinical Nutrition and Metabolic Care, 18(2), 147-154. https://doi.org/10.1097/MCO.0000000000000145.

Samaram, S., Mirhosseini, H., Tan, C. P., \& Ghazali, H. M. (2013). Ultrasound-assisted extraction (UAE) and solvent extraction of papaya seed oil: Yield, fatty acid composition and triacylglycerol profile. Molecules, 18(10), 12474-12487. https://doi. org/10.3390/molecules181012474.

Sarmento, A., Barros, A., Fernandes, Â., Carvalho, A., \& Ferreira, I. (2015). Valorization of traditional foods: Nutritional and bioactive properties of Cicer arietinum L. And Lathyrus sativus L. Pulses. Journal of the Science of Food and Agriculture, 95(1), 179-185. https://doi.org/10.1002/jsfa.6702.

Sodeifian, G., Ardestani, N. S., Sajadian, S. A., \& Moghadamian, K. (2018). Properties of Portulaca oleracea seed oil via supercritical fluid extraction: Experimental and optimization. The Journal of Supercritical Fluids, 135, 34-44. https://doi.org/10.1016/j. supflu.2017.12.026 November 2017.

Stroescu, M., Stoica-Guzun, A., Ghergu, S., Chira, N., \& Jipa, I. (2013). Optimization of fatty acids extraction from Portulaca oleracea seed using response surface methodology. Industrial Crops and Products, 43(1), 405-411. https://doi.org/10.1016/j. indcrop.2012.07.051.

Tavarini, S., Castagna, A., Conte, G., Foschi, L., Sanmartin, C., Incrocci, L., et al. (2019). Evaluation of chemical composition of two linseed varieties as sources of healthbeneficial substances. Molecules, 24(20), https://doi.org/10.3390/ molecules24203729.

Tayel, A. A., Shaban, S. M., Moussa, S. H., Elguindy, N. M., Diab, A. M., Mazrou, K. E., et al. (2018). Bioactivity and application of plant seeds' extracts to fight resistant strains of Staphylococcus aureus. Annals of Agricultural Science, 63(1), 47-53. https:// doi.org/10.1016/j.aoas.2018.04.006.

Tocher, D. R. (2015). Omega-3 long-chain polyunsaturated fatty acids and aquaculture in perspective. Aquaculture, 449, 94-107. https://doi.org/10.1016/j.aquaculture.2015. 01.010.

Tocher, D. R., Betancor, M. B., Sprague, M., Olsen, R. E., \& Napier, J. A. (2019). Omega-3 long-chain polyunsaturated fatty acids, EPA and DHA: Bridging the gap between supply and demand. Nutrients, 11(1), 1-20. https://doi.org/10.3390/nu11010089.

Uquiche, E., Jeréz, M., \& Ortíz, J. (2008). Effect of pretreatment with microwaves on mechanical extraction yield and quality of vegetable oil from Chilean hazelnuts (Gevuina avellana Mol). Innovative Food Science \& Emerging Technologies, 9(4), 495-500. https://doi.org/10.1016/j.ifset.2008.05.004.

Vioque, J., Pastor, J., \& Vioque, E. (1994). Estudio de la composición en ácidos grasos del aceite de las semillas en algunas plantas silvestres españolas. Grasas y Aceites, 45(3), 161-163. https://doi.org/10.3989/egeogr.2001.i245.267.

Wang, S., Zhu, F., \& Kakuda, Y. (2018). Sacha inchi (Plukenetia volubilis L.): Nutritional composition, biological activity, and uses. Food Chemistry, 265(December 2017), 316-328. https://doi.org/10.1016/j.foodchem.2018.05.055.

Yoshida, H., Tomiyama, Y., Hirakawa, Y., \& Mizushina, Y. (2006). Microwave roasting effects on the oxidative stability of oils and molecular species of triacylglycerols in the kernels of pumpkin (Cucurbita spp.) seeds. Journal of Food Composition and Analysis, 19(4), 330-339. https://doi.org/10.1016/j.jfca.2004.10.004. 